Article

\title{
Does Regulation Influence Microfinance Institutions to Be More Client-Responsive?
}

\author{
Zakir Morshed ${ }^{1, *}$, Mohshin Habib ${ }^{2}$ and Christine Jubb ${ }^{2}$ \\ 1 Torrens University Australia Business School, Torrens University Australia, 196 Flinders St, \\ Melbourne, VIC 3000, Australia \\ 2 Swinburne Business School, Swinburne University of Technology, John Street, Hawthorn, VIC 3122, \\ Australia; mhabib@swin.edu.au (M.H.); cjubb@swin.edu.au (C.J.) \\ * Correspondence: zakir.morshed@laureate.edu.au
}

Received: 1 September 2020; Accepted: 14 October 2020; Published: 20 October 2020

check for updates

\begin{abstract}
The regulation of microfinance services is likely to have a wide-ranging influence on the microfinance sector, particularly on institutions and their clients. This paper reveals the impact of a specific regulatory regime, the "Microcredit Regulatory Authority Act, 2006", enacted by the Bangladesh government to monitor and supervise nonprofit nongovernment organizations (NGOs). We analyzed survey and interview data provided by clients of both nonprofit microfinance institutions (MFIs) registered under the Act and nonprofit institutions that are unregistered, all lending only to women. Client-level analysis using fixed effects for specific MFI membership is applied, focusing on the role of regulation by comparing protections as consumers of financial intermediations in terms of financial literacy, awareness, and status of clients of registered and unregistered MFIs. We found compelling evidence of a positive association between the financial status, financial literacy, and financial awareness of clients of registered MFIs, but not unregistered MFIs. These findings support the need for MFIs to implement consumer protection measures and inform their consumers about key issues to achieve improved client outcomes.
\end{abstract}

Keywords: consumer protection; nongovernment organization; regulation; microfinance; consumer awareness; Bangladesh

\section{Introduction}

Despite the long history of microfinance (Gatto 2018), in the last decade regulatory issues within the microfinance sector have received considerable attention from multilateral development organizations (e.g., the Asian Development Bank, The World Bank, United Nations), central banks, and governments of both developed and developing countries (Islam and Mamun 2011). In that context, with the largest microfinance sector in the world, the government of Bangladesh passed the "Microcredit Regulatory Authority Act, 2006" to, amongst other things, improve governance practices within nongovernment organization (NGO) microfinance institutions (MFIs) (hereafter NGO-MFIs) for the welfare of their clients (Microcredit Regulatory Authority 2010). In a Bangladesh context, MFIs focus almost exclusively on poor women, and it is women who make the best microcredit recipients (Drago and Gatto 2018).

Microcredit represents a powerful tool to enhance livelihoods, reduce poverty and increase financial inclusion for those without the collateral that provides access to lending by conventional financial institutions. Women, despite being highly vulnerable, especially in Bangladesh where the World Economic Forum Global Gender Gap Index (World Economic Forum (WEF) (2020)) reveals a rank of 141 from 153 countries in terms of Economic Participation and Opportunity, have been found to utilize microfinance loans more beneficially for family resilience than males (Dzanku 2019) and also to exhibit higher relative repayment rates (Armendáriz and Morduch 2010; D'Espallier et al. 2011; 
Shahriar et al. 2020). This latter feature is thought to be due to the innate trustworthiness and collaboration developed within female groups by the social capital inherent in the group lending model adopted by many MFIs, including in Bangladesh (Berge et al. 2016; Shahriar et al. 2020).

Given the effectiveness of microfinance in reducing poverty, facilitating entrepreneurship, and enhancing financial and social inclusion, it is important that organizations servicing these vulnerable clients act with propriety and probity and are financially sustainable. Previous studies have claimed that the need for regulation and supervision of MFIs arises from several considerations. These include protecting the interests of small depositors, ensuring proper terms of credit, financial discipline, and educating consumers so that they are aware of their rights (Ahmed 2013; Akash et al. 2010; Bakker et al. 2014; Baten 2009; Charitonenko and Rahman 2002; Jackson and Islam 2005; Miah 2006; Rahman and Luo 2012; Rashid 2010; Yuge 2011). Brix and McKee (2010) argued that as competition increased, MFIs and their clients have faced a variety of consumer protection challenges, including pricing transparency, appropriate product sales techniques and collection practices, incentives for client over-indebtedness, and poor client financial literacy. Gutiérrez-Nieto et al. (2017) supported the need to improve MFI consumers' awareness (knowledge about their rights and financial literacy), especially of the risks involved in over-indebtedness. Wickramasinghe and Fernando (2017) argued that education of microcredit users is needed to deter borrowing for income and consumption smoothing and encourage use of funds for income generation. Murendo and Mutsonziwa (2017) found that greater financial literacy positively influenced saving through MFIs.

Cohen (2013, p. 179) editorialized that " ... financial literacy, financial education, and financial capability ... are seen by many as integral parts of the financial inclusion agenda". He went on to say that the "... sudden rise of personal financial management capabilities, however, should not blind us to the reality that this is a nascent field and [we] still have much to learn about not only good practice but also what is measurable in terms of impact". Consistent with Huston (2010) and Sayinzoga et al. (2016), we define financial literacy as consumers' awareness, skills, and knowledge, enabling them to make informed, effective decisions about financial resources. Nawaz (2015) concluded that client awareness (financial literacy) is more important than access to credit itself, and should be the focus of all future microfinance programs, consistent with MFIs playing an important role in social development (Jha 2016; D'Espallier et al. 2016). However, client awareness and protection remain comparatively under-researched in developing countries (Sayinzoga et al. 2016; Islam and Simpson 2018). This study responds to this lack of research and examines the role of regulation in encouraging microfinance client awareness about their rights and protection of consumers by MFIs.

This research is focused on whether the registration of nonprofit MFIs under the Bangladesh “Microcredit Regulatory Authority Act, 2006" (Microfinance Regulatory Authority Act 2006) (hereafter MRA Act-2006) is associated positively with enhancing MFI clients' financial awareness or their financial status. To investigate this issue, we gained permission from both registered and unregistered ${ }^{1}$ NGO-MFIs and their exclusively female clients to participate in highly structured interviews during a period after the implementation of the MRA Act-2006.

The findings provided strong evidence that clients' financial status is positively associated with their awareness and that the financial literacy of clients of regulated MFIs is higher than that of clients of unregulated MFIs. Given the findings, this paper provides insight and contribution by assisting policymakers, governments, and donors to better understand the microfinance sector, and to potentially make decisions more effectively in the interests of consumer protection.

\subsection{Background}

Although it continues to improve, Bangladesh has one of the lowest per capita income levels in the world (The World Bank 2018). The microfinance sector in Bangladesh has undergone four

1 In this study, the terms "regulated" and "unregulated" are used synonymously with the terms "registered" and "unregistered". 
distinct development phases: the "Action phase" in the 1970s, the "Microcredit Development phase" in the 1980s, the "Consolidation phase" in the 1990s, and the "Expansion phase" from 2000 onwards (Bedson 2009). Significant growth in microfinance saw Bangladesh host the then largest microfinance sector in the world. However, in the absence of any form of accountability to the government or any other authority, particularly for nonprofit NGO-MFIs in the country, significant challenges were present with issues related to consumer protection, institutional transparency, outreach, and sustainability (Alamgir 2009; Bedson 2009).

Various authorities, such as the Ministry of Finance and the Central Bank, started thinking about the need for an appropriate regulatory framework for the nonprofit NGO-MFI sector from the mid-1990s (Alamgir 2009; Rashid 2010). The sustainability of the industry from both the government's perspective and in terms of the environmental, social, and economic sustainability of the NGO-MFIs themselves was likely to have been an important consideration (Rusciano et al. 2019). Action came in the form of the MRA Act-2006, which established the Microcredit Regulation Authority (MRA) as the regulatory and supervisory body with oversight of the sector. The core mission of the MRA is to ensure the transparency and accountability of microfinance operations of NGO-MFIs (Microcredit Regulatory Authority (MRA) (2011)). All MFIs that met the required loan portfolio (BDT 4 million) and number of borrowers (1000) were to be registered or cease to operate by March 2010.

\subsection{Clients' Awareness and Financial Literacy in a Microfinance Context}

Clients' financial awareness and the protection of their rights are critical to the objectives of microfinance programs. However, MFI clients are often unaware of their rights as consumers, including, for instance, their rights to privacy, to know the terms and conditions of their loans and interest rate, or the debt collection policies of their MFI (Perdomo 2008). This lack of knowledge is not unusual even in more conventional banking contexts (e.g., (Lee et al. 2019)). Many clients do not even expect transparency or accountability to be fundamental components of their financial rights (Chaudhury and Matin 2002). However, it is well-known that financial literacy training culminates in greater financial inclusion (Bongomin et al. 2017), greater savings and borrowing, increased likelihood of starting new income-generating activities (Sayinzoga et al. 2016), and improvement in repayment rates and productive use of loans (Epstein and Yuthas 2017), although it does not necessarily mitigate over-indebtedness (Schicks 2014).

Examples exist of the abuse, mistreatment, and exploitation of loan collection concerning poor, vulnerable clients in Bangladesh (Banerjee and Jackson 2017; Maîtrot 2018). Banerjee and Jackson (2017) found incidences of client abuse, humiliation, and malpractice by microfinance loan officers and their employees. Banerjee and Jackson (2017) found that MFIs in Bangladesh often use aggressive loan recovery strategies that cause humiliation and disrespect, and de-motivate clients to repay. Maîtrot (2018) found that clients with regular repayments faced forceful loan renewal, terming this as "practice drift" by MFI field staff, as distinct from "mission drift" at the head office level. There have also been instances of fraud and misappropriation of clients' deposits (Jackson and Islam 2005). Compounding the problem is that financial literacy is very low in Bangladesh (Khalily and Miah 2015; Khalily 2016). Both strong consumer protection and client awareness and financial literacy are necessary to safeguard the interests of MFI clients from the adverse effects of undesirable practices by financial intermediaries (Rozas et al. 2011).

There are two strong key rationales for proper monitoring and regulation of the nonprofit NGO-Microfinance sector. First, from a client-centered perspective, to safeguard clients from all forms of abuse and protect their rights. Second, from an institutional perspective, to improve the governance and accountability of microfinance operations. This article investigates whether there is a difference in female clients' financial literacy and awareness of their rights in a financial context when dealing with their institutions, contingent on the regulatory status of their MFI.

Section 2 provides a review of the literature on regulation in a microfinance context. Section 3 discusses the normative expectations of consumer protection specific to microfinance; it is followed by 
Section 4, where hypotheses are developed. In Section 5, the data gathering and analysis methods utilized are explained. Sections 6 and 7 report the results and draw conclusions, respectively.

\section{Theoretical Development and Prior Literature}

In terms of theory, the MRA's actions can be explained by the theory of change, which asserts that interventions can lead to desired results (Gertler et al. 2011). The actions can also be explained by the public interest theory of regulation that argues interventions are necessary when a market failure exists in order to benefit the public interest (Deegan 2014). In terms of MFI client literacy, Thaler (1985) theory of mental accounting shows that individuals think about their financial decisions in terms of budgets for various mental expense categories, but not in terms of interest rates and the time value of money.

Several studies (e.g., (Rashid 2010; Jackson and Islam 2005; Miah 2006; Rahman and Luo 2012; Ahmed 2013; Akash et al. 2010; Yuge 2011; Charitonenko and Rahman 2002; Baten 2009)) examined the microfinance sector in terms of registration requirements, financial reserve requirements, agreement with prudential accounting norms, and guidelines and supervision of operations and reporting systems, among other aspects. These studies mostly emphasized the significance and normative requirements of supervision and regulation of the sector. However, scant scholarly research exists on the role of regulation in its association with client outcomes, with industry reports more common.

Some studies that fall under the theme of MFIs and client financial literacy focused on women's empowerment and client protection (Beltran 2007; Brix and McKee 2010; Cheston and Kuhn 2002; Herman 2012; Kline and Sadhu 2011; Lee et al. 2019). A number of studies (Ghosh et al. 2014; Kalra et al. 2015; Rozas et al. 2011; Tiwari et al. 2008) examined issues concerning clients' financial literacy in terms of MFI offerings. While the majority of these studies had a similar focus on the importance of client protection and training, only two (Ghosh et al. 2014; Tiwari et al. 2008) highlighted the importance of regulation of MFIs.

In an industry report, Ghosh et al. (2014) used qualitative interview data to examine the impact on clients of MFI regulation by the Reserve Bank of India (RBI). Interviews were conducted with clients, executives, and employees of MFIs, and representatives of three banks as lenders to MFIs. Nine MFIs and their clients were interviewed during 2010-2011. The findings showed that external regulation of MFIs' governance not only ensured proper monitoring of and accountability, but also ensured that all stakeholders' interests were taken into account. Ghosh et al. (2014) suggested that regulation of MFIs is important for their clients' financial literacy, health, and education, and most crucially, the knowledge and skills required in exercising the clients' rights and responsibilities as consumers.

Tiwari et al. (2008) examined—in two phases, for 299 and 40 clients of two MFIs, separately—clients' understanding of their loan contracts and assessed the implications of this understanding for policy. The findings showed that small borrowers could identify their loan size, loan duration, and weekly installments. However, they had a poor understanding of their loan interest rate or total interest expense. Troublingly, most clients found what are commonly viewed as coercive collection practices to be acceptable. The results indicated that clients think about their loans in terms of how much they owe weekly. Tiwari et al. (2008) observed that a top-down regulatory approach incorrectly assumes that all borrowers can calculate and understand their loan and interest rates. However, the study did not differentiate between regulated and unregulated MFIs or their clients.

Kalra et al. (2015) developed a financial awareness index to measure the awareness and skills of MFI clients. The index scored financial awareness education and knowledge of loans and insurance for clients from four Indian MFIs. The index also evaluated clients' financial, product analysis, and computing skills. The findings showed that clients of one MFI were more aware of their rights and the products offered compared to clients of the other three MFIs. The MFIs that provided training and educated their clients about financial and business matters scored better than MFIs offering no training. The results indicated that MFIs could play a significant role in increasing the awareness and knowledge of their clients concerning issues falling under consumer protection. 
In terms of industry reports, Rozas et al. (2011) and Bansal et al. (2013) reported on the extent to which seven client protection principles developed in 2008 under a worldwide sector initiative known as the "Smart Campaign" have been implemented successfully. Since then, a subsequent report acknowledged the need to tailor this campaign to the stage of development of microfinance in each country (Shinozaki et al. 2017). By 2013, over 3900 endorsers of the initiative existed, coming from 130 countries, and including 1359 MFIs. The seven client protection principles they investigated include: (i) MFIs and their clients should have adequate knowledge and understanding of appropriate product design and delivery; (ii) prevention from over-indebtedness; (iii) transparency; (iv) appropriate terms and conditions and responsible pricing; (v) fair and respectful treatment of clients; (vi) privacy of client records; and (vii) proper mechanisms for complaint resolution.

Rozas et al. (2011) collected 479 independent third-party ratings ${ }^{2}$ of client protection practices plus self-reported data covering 300 MFIs across 130 countries for 2008-2011. The results revealed that a basic level of client protection performance was widespread in the governance practices of many MFIs. On a scale of 1-5, the privacy of client data scored 4.4, prevention from over-indebtedness, transparency, and fair and respectful treatment of clients each scored 3.8, mechanisms for complaint resolution scored 3.7, and responsible pricing scored 3.5. Notably, poorer MFI performers were found in Sub-Saharan Africa and East-Asia Pacific, and also amongst smaller MFIs in most countries.

Bansal et al. (2013) followed up and collected 58 MFI self-assessments and 18 external assessments by Smart Accredited Assessors for 2011-2013. Findings based on the more objective external assessments revealed weaknesses in two of the smart campaign principles: complaints resolution and privacy of client data. Only half of the 18 MFIs had positive external assessments for preventing over-indebtedness and transparency. However, strong practices were found for monitoring over-indebtedness, offering product flexibility in terms of loan conditions, and sharing data with a credit bureau. However, neither Rozas et al. (2011) nor Bansal et al. (2013) included MFI regulatory status in their analyses.

\section{Consumer Protection and Regulation in the Microfinance Sector}

The MRA Act-2006 includes content on the "Rights of and responsibilities to nonprofit NGO-MFIs and their clients", ${ }^{3}$ and the MRA has published rules, guidelines, notices, and circulars since the passage of the Act. These rules were circulated to all NGO-MFIs, whether they were registered or not. Subsequently, the MRA published its most comprehensive circular/rules in November 2010. Some of these rules relate to clients of NGO-MFIs, and include clauses on client protection, improving client awareness of rights regarding their financial institutions, withdrawals, and adjustments to client savings, knowledge and information about client savings, and clients' duties.

\section{Hypothesis Development}

From the review of prior research, it can be seen that few studies accounted for the regulatory status of MFIs of which clients are members. It is this omission that this study sought to address. Bangladesh is ideally suited to this type of investigation since a clear delineation between regulated and unregulated nonprofit NGO-MFIs followed the passage of the MRA Act-2006. The establishment of the Authority, whether explained by the public interest theory of regulation (Deegan 2014) or the theory of change (Gertler et al. 2011), has been argued to have encouraged MFIs to practice principles of client protection. Furthermore, the issuance in 2010 of comprehensive rules and other guidance by the Authority is likely to have influenced regulated MFIs more than unregulated MFIs to encourage

2 Third-party on-site evaluations included ratings by the specialized microfinance rating agencies MicroFinanza Rating and PlanetRating; due diligence evaluations by the asset managers BlueOrchard, Incofin, Symbiotics, and Triple Jump; and assessments conducted by the Smart Campaign itself. Beisland and Mersland (2012) review the drivers of third-party ratings.

3 http://www.mra.gov.bd/index.php?option=com_content\&view=article\&id=22\&Itemid=40. 
the acquisition of financial literacy and awareness of their rights by clients. Given this, the following hypothesis was developed:

Hypothesis 1 (H1). Clients of regulated nonprofit, nongovernment organization microfinance institutions are associated with higher financial literacy compared with clients of unregulated counterparts.

Clients of registered MFIs are expected to have higher financial literacy compared to clients of unregistered MFIs; they are thus expected to be more in control of their financial status than clients of unregistered MFIs. This premise leads to Hypotheses 2 and 3:

Hypothesis 2 (H2). Clients of regulated nonprofit, nongovernment organization microfinance institutions are associated with higher financial status than clients of unregulated counterparts.

Hypothesis 3 (H3). Clients with higher rather than lower financial literacy are associated with higher financial status.

To examine the role of regulation, Hypothesis 1 examines the relationship between clients' financial literacy and their NGO-MFIs' status; that is, being a member of a regulated or unregulated NGO-MFI. Hypotheses 2 and 3 examine, respectively, the relationship between client financial literacy and NGO-MFI status (regulated/unregulated) and clients' financial status.

\section{Research Method}

A structured interview guide constructed for a wider study, informed by the MRA Act-2006 and MRA rules and guidelines, and translated into Bengali, was used by the first-named researcher to collect primary data through face-to-face interviews with NGO-MFI clients. The interview guide, designed to be suitable for respondents with little literacy, was validated by four high-level nonparticipant MFI experts working in the field, three of which were from Bangladesh, and revised according to their comments. Table 1 reports the final 12 structured questions to which participating NGO-MFI clients were asked to respond anonymously. Demographic data were also collected.

\subsection{Population and Sampling}

In seeking cooperation from nonprofit NGO-MFIs and their clients, stratified random sampling was used to select 89 NGO-MFIs from 651 (14 percent) that had operated since 2001 and had registered with the MRA in 2006 or later. Additionally, the MIX Market (2012) and Credit Development Forum ${ }^{4}$ (Credit Development Forum (CDF) (2013)) databases were used to randomly select $60^{5}$ then currently operating unregistered MFIs operating since $2001^{6}$.

This 10-year timeline was considered important in examining the impact of regulation on NGO-MFI clients' awareness of protection issues (Chowdhury 2000). MFIs were approached until the predetermined number in each stratified sample agreed to participate. The NGO-MFIs were located across the country, with both registered and unregistered NGO-MFIs operating in rural and urban areas.

CDF, a nonprofit organization, and the National Association of Bangladesh Microfinance, were established in 1992 to provide capacity, networking and advocacy, and building resource linkages between MFIs in Bangladesh. A survey is conducted annually by CDF to gather MFIs' financial data.

5 There were 107 unregistered MFIs that reported to CDF in 2012. However, there are more than 500 unregistered MFIs working in Bangladesh without any formal recognition from the government or CDF (according to the CDF president).

6 It is interesting to note that, in more recent years, the MRA does not acknowledge the existence of unregulated MFIs. 
Table 1. Structured interview guide and client yes response frequencies.

\begin{tabular}{|c|c|c|c|c|c|c|c|c|}
\hline & \multirow[t]{2}{*}{ Questions and Number (\%) of Yes Responses } & \multirow{2}{*}{$\begin{array}{c}\text { Full Sample } \\
(\mathrm{N}=342)\end{array}$} & \multicolumn{2}{|c|}{$\begin{array}{l}\text { Unregistered MFIs } \\
\qquad(\mathrm{N}=142)\end{array}$} & \multicolumn{2}{|c|}{$\begin{array}{l}\text { Registered MFIs } \\
(\mathrm{N}=200)\end{array}$} & \multirow{2}{*}{ Pearson $\mathrm{Chi}^{2}$} & \multirow[t]{2}{*}{$p$-Value } \\
\hline & & & $\mathbf{N}$ & $\%$ & $\mathbf{N}$ & $\%$ & & \\
\hline 1 & $\begin{array}{l}\text { Do you know the types of loans and other facilities } \\
\text { available from your MFI? }\end{array}$ & 36.0 & 29 & 20.4 & 94 & 47.0 & 25.470 & 0.000 \\
\hline 2 & $\begin{array}{l}\text { Did loan officers/lenders explain to you the terms and } \\
\text { conditions of the loan? }\end{array}$ & 32.2 & 15 & 10.6 & 95 & 47.5 & 51.925 & 0.000 \\
\hline 3 & $\begin{array}{l}\text { Do you know the interest rate (per month) on your loan } \\
\text { and savings charged by and paid by your MFI? }\end{array}$ & 58.5 & 0 & 0.00 & 200 & 100.0 & 342.000 & 0.000 \\
\hline 4 & $\begin{array}{l}\text { Do you maintain any loan or savings passbook given by } \\
\text { your MFI? }\end{array}$ & 72.2 & 69 & 48.6 & 178 & 89.0 & 67.588 & 0.000 \\
\hline 5 & $\begin{array}{l}\text { Do loan officers/lenders give you a copy of the } \\
\text { promissory note for your records? }\end{array}$ & 58.5 & 57 & 39.9 & 143 & 71.5 & 174.489 & 0.000 \\
\hline 6 & $\begin{array}{l}\text { Can you get information about your loan and savings } \\
\text { from your branch office any working day? }\end{array}$ & 59.7 & 12 & 8.5 & 192 & 96.0 & 264.448 & 0.000 \\
\hline 7 & $\begin{array}{l}\text { Do you know about the fees, premium, and settlement of } \\
\text { claim of your insurance service? }\end{array}$ & 16.1 & 3 & 2.1 & 52 & 26.0 & 35.11 & 0.000 \\
\hline 8 & Do you have savings with your MFI? & 71.4 & 45 & 31.7 & 199 & 99.5 & 186.773 & 0.000 \\
\hline 9 & $\begin{array}{l}\text { Can you withdraw your savings (partially or fully) from } \\
\text { your MFI (if your loan is cleared)? }\end{array}$ & 98.0 & 135 & 95.1 & 200 & 100.0 & 10.065 & 0.002 \\
\hline 10 & Do you have any other voluntary savings in your MFI? & 89.5 & 126 & 88.7 & 180 & 90.0 & 0.142 & 0.707 \\
\hline 11 & Do you know what your service charge is? & 58.5 & 0 & 0.00 & 200 & 100.0 & 342.000 & 0.000 \\
\hline 12 & Do you earn any interest on your savings? & 58.5 & 0 & 0.00 & 200 & 100.0 & 342.000 & 0.000 \\
\hline
\end{tabular}


Once cooperation from 149 MFIs was secured, the questionnaire was pre-forwarded for information, and meetings were then arranged with the $\mathrm{CEO} /$ managing director of each MFI. Permission was sought to visit NGO-MFI branch offices at client meeting times. Branch office names and locations were publicly available from websites, MRA reports, or published MFI reports. A generic formal letter of approval that introduced the researcher to branch office managers was sought and received from each NGO-MFI executive.

On receipt of consent from each NGO-MFI with a letter of introduction, random sampling was again used to select three branches, whereupon branch managers were approached by phone until three from each NGO-MFI agreed to assist in recruiting clients for a 10-15 min interview by introducing the researcher before a branch meeting. Thus, participating NGO-MFI executives had no knowledge of, nor could wield any influence over, which branch managers were approached or agreed to participate. The researcher then attended branch offices at pre-arranged times to recruit clients and interviewed those willing. The response sheets were completely anonymous; with client responses to both instrument and demographic questions were recorded by the researcher. All clients were female, as is the norm in Bangladesh. For the registered MFIs, 71 percent were in urban areas. For the unregistered MFIs, 65 percent were in urban areas. Thus, the urban-rural partition was similar for both registered and unregistered NGO-MFIs.

\subsection{Model Development}

It was anticipated that, similar to the results of Kalra et al. (2015), responses to the 12 questions related to consumer protection reported in Table 1 would need to be factor-analyzed with factor scores substituted for the raw data due to high multicollinearity. For the testing of Hypothesis 1 , the dependent variable was represented by client protection factor scores. The hypothesis variable was the regulatory status of the NGO-MFI. Since financial literacy and awareness of consumer issues were expected to be positively associated with the presence of a client-owned microenterprise and the client's level of education, we included these demographic characteristics as control variables, and tested the following ordinary least squares (OLS) regression equation:

$$
\begin{aligned}
& \text { Consumer protection knowledge }(\text { Factor Scores } i t)=\beta_{0}+\beta_{1} \text { Regulated }_{i t}+\beta_{2} \text { Microent }_{i t}+ \\
& \beta_{3} \text { Education }_{i t}+\varepsilon_{\text {it }}
\end{aligned}
$$

\begin{tabular}{|c|c|c|}
\hline Variable & Pred. Dir. & Definition and measure \\
\hline \multicolumn{3}{|c|}{ Dependent Variable (Financial Literacy) } \\
\hline Factor Score(s) & & Factor analysis of client responses \\
\hline \multicolumn{3}{|c|}{ Hypothesis Variable } \\
\hline Registered & + & Whether the client's MFI is regulated (coded yes $=1,0$ otherwise) \\
\hline \multicolumn{3}{|c|}{ Control Variables } \\
\hline Microent & $=+$ & A self-declared client microenterprise exists (coded yes $=1$, otherwise 0 ) \\
\hline Education & + & The client has some schooling (coded yes $=1$, otherwise 0 ) \\
\hline
\end{tabular}

where for client $i$ at time $t$ :

For the testing of Hypothesis 2 and Hypothesis 3, the factor scores and regulated status were expected to be positively associated with client financial status. Client financial status was also expected to be positively associated with client age, education, marital status, number of children, and owning a microenterprise. Children often work and contribute to family income, so it was not clear in which direction this variable may affect financial status.

$$
\begin{aligned}
& \text { Financial Statusit }=\beta_{0}+\beta_{1} \text { Factor Score }(s)_{i t}+\beta_{2} \text { Regulated }_{i t}+\beta_{3} \text { Age }_{i t}+\beta_{4} \text { Married }+\beta_{5} \text { Children }_{i t} \\
& +\beta_{6} \text { Microent }_{i t}+\beta_{7} \text { Education }_{i t}+\varepsilon_{i t}
\end{aligned}
$$

where, for client $i$ at time $t$, variables were defined and measured as per Equation (1), except for: 


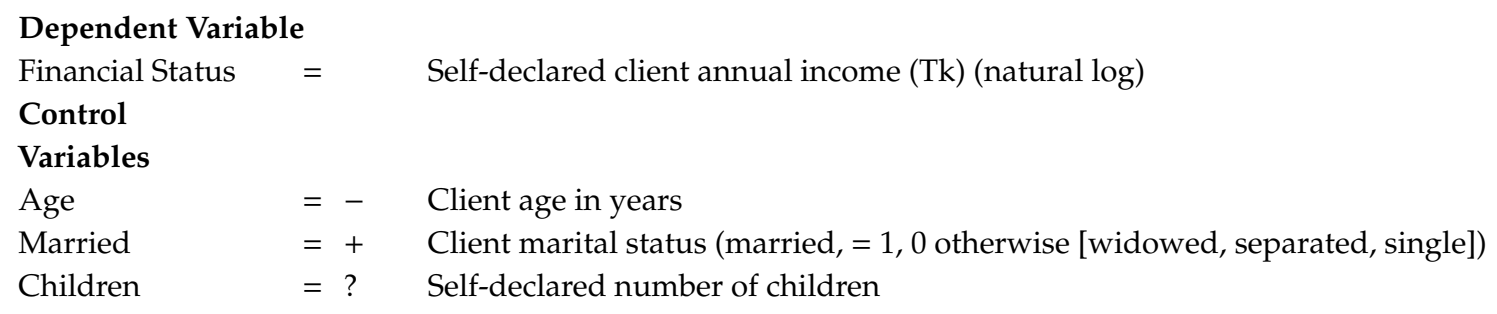

In estimating all models, we used robust regression clustering on client membership of a specific NGO-MFI.

\section{Results}

The sampled 149 branch offices (89 and 60 registered and unregistered, respectively) of MFIs from all parts of Bangladesh were visited to conduct client interviews during the five months from November 2013 to March 2014. A total of 387 clients were interviewed (212 and 175 clients of registered and unregistered NGO-MFIs, respectively), but some clients did not respond to all questions and 342 (88 percent) complete observations for 147 NGO-MFIs were used in the analysis (200 and 142 clients of registered and unregistered MFIs, respectively).

\subsection{Descriptive Statistics}

In addition to the structured interview questions, Table 1 reports descriptive statistics for responses to each question and whether or not there is a significant difference in affirmative responses by clients of registered compared with unregistered NGO-MFIs. The Cronbach's alpha for the 12 questions was 0.878. However, for three questions, no clients of unregistered NGO-MFIs responded "Yes". These questions relate to Q3 - participants' knowledge of the interest rate (per month) on loans and savings charged by their MFI; Q11—whether or not the service charge is known; and Q12—knowledge of whether or not interest is earned on their savings. Consequently, significant Chi squared values $(p<0.001)$ were recorded for the clients of regulated compared with nonregulated MFIs, as shown in Table 1.

There are also significant Chi squared differences $(p<0.001)$ for "Yes" responses by clients of registered (47 percent) and unregistered (26 percent) NGO-MFIs to Q1, concerning knowledge of types of loans, Q2, concerning explanations by loan officers (48 and 11 percent, respectively), Q4, concerning maintenance of a savings or passbook (68 and 49 percent, respectively), Q5, concerning receipt of promissory notes (72 and 40 percent, respectively), Q6, concerning accessibility of loan and savings information (96 and 9 percent, respectively), Q7 concerning knowledge of fees, premiums and claims regarding insurance (26 and two percent, respectively), Q8, concerning knowledge of savings (100 and 32 percent, respectively), Q9, concerning knowledge of ability to withdraw savings (100 and 95 percent, respectively), and Q10, concerning knowledge of other, voluntary savings (99 and 32 percent, respectively).

Table 2 reports the Pearson's correlations between responses to questions 1-12. As was anticipated, some of the Pearson's correlations were unitary (e.g., Q11 and Q12), with others very high (e.g., 0.879 between Q3 and Q6 and 0.739 between Q3 and Q9) and correlations with the variable registered/unregistered were perfect in some cases, meaning that a singular matrix due to high multicollinearity in the factor analysis will not allow estimation of the Kaiser-Meyer-Olkin (KMO) measure of sampling adequacy. Hence, responses to questions 3, 11, and 12 were omitted. Without these three questions, the Cronbach's alpha for the remaining nine questions was reduced to 0.720 , which is considered adequate. 


\subsection{Factor Analysis}

As mentioned, to reduce the number of variables, the nine questions reported in Table 1 where responses were not perfectly predictive of MFI registration status were factor analyzed (i.e., questions $1,2,4,5,6,7,8,9$, and 10). Only observations for which all data were present and also met the regression variable requirements are included, resulting in a sample of 342 client observations. The Table 2 correlations between client responses to these questions reveal that a substantial number are above 0.30 and the inverse correlation matrix reported in Appendix A-Table A1 confirm that most correlations among the variables are significant and the negative partial (anti-image) covariances and correlations reported in Appendix A-Table A2 reveal only two correlations above 0.70 (Q6 and Q8). Hence, the responses are considered suitable for factor analysis (Hair et al. 2014, p. 101). The Kaiser-Meyer-Olkin measure of sampling adequacy was 0.651 (Appendix A-Table A3, which is low (Hair et al. 2014, p. 102), but it needs to be remembered that responses to three questions that perfectly predicted NGO-MFI registration status were omitted from the analysis and Bartlett's test of sphericity, which provides the statistical significance that the correlation matrix has significant correlations among at and a Chi-square of $1106.19(p<0.001)$ (Appendix A-Table A3), enabling the factor analysis to proceed.

The scree plot (Appendix A-Figure A1), communalities (Appendix A-Table A4), and eigenvalues greater than one (Appendix A-Table A5) (Hair et al. 2014, p. 107) suggested that three factors capture the variability in the responses best. The lowest communality was 0.495 and the next lowest 0.520 with the rest above 0.6 , so the proportion of variance explained for each variable explained by the components was acceptable to proceed. Together, these three factors explained over 69 percent of the variance in the client responses with 32 percent for Factor 1, 21 percent for Factor 2, and 16 percent for Factor 3.

The component matrix (Appendix A-Table A6) plus the reproduced correlations (Appendix A-Table A7) for the nine questions confirm the earlier outcomes. An oblimin rotation with Kaiser normalization was chosen since the factors were expected to be correlated (Hair et al. 2014). Table 3 presents the rotated $\left(\right.$ oblimin $^{7}$ ) principal components analysis loadings for the client responses to the included questions. The structure matrix is reported in Appendix A-Table A8. The loadings are all above 0.50 with at least two questions loading on each component, so a simple structure results, as was the aim. The three components were deemed to represent "Personalized information about savings/loan basics", "General information about loans", and "Knowledge of access to savings".

For the first theme, "Personalized information about savings/loan basics", the items relate to the client's knowledge about personal financial information, such as their loan/savings. Client responses to questions consisted of "interest charged on their loans and savings account by respective MFIs", "access to information from MFIs during business hours", "having passbook linked with their account", and providing receipts to clients for financial transactions by respective MFIs.

In the second theme, "General information about Loans", the items relate to client knowledge about their financial service provider. The questions were focused on the types of loan available, fees premium, settlements of claims for insurance (if any), and whether or not the loan officer explained the terms and conditions of their loan. For the third theme, "Knowledge of access to savings", the items relate to the clients' knowledge about their rights to access their savings and their knowledge of the voluntary nature of savings. 
Table 2. Pearson's correlations.

\begin{tabular}{|c|c|c|c|c|c|c|c|c|c|c|c|c|c|}
\hline $\begin{array}{l}\text { Questions; Yes } \\
\text { Responses = } 1\end{array}$ & $\begin{array}{l}\text { Registered } \\
\text { MFI = Yes }\end{array}$ & Q1 & Q2 & Q3 & Q4 & Q5 & Q6 & Q7 & Q8 & Q9 & Q10 & Q11 & Q12 \\
\hline Q1 & $0.273^{* * *}$ & & & & & & & & & & & & \\
\hline Q2 & $0.390^{* * *}$ & $0.710^{* * *}$ & & & & & & & & & & & \\
\hline Q3 \# & $1.000^{* * *}$ & $0.273^{* * *}$ & $0.390^{* * *}$ & & & & & & & & & & \\
\hline Q4 & $0.445^{* * *}$ & -0.011 & $0.189 * *$ & $0.445^{* * *}$ & & & & & & & & & \\
\hline Q5 & $0.714^{* * *}$ & $-0.117 *$ & -0.038 & $0.714^{* * *}$ & $0.526^{* * *}$ & & & & & & & & \\
\hline Q6 & $0.879^{* * *}$ & $0.244^{* * *}$ & $0.286^{* * *}$ & $0.879^{* * *}$ & $0.448^{* * *}$ & $0.661^{* * *}$ & & & & & & & \\
\hline Q7 & $0.320 * * *$ & $0.402 * * *$ & $0.465^{* * *}$ & $0.320^{* * *}$ & $0.236^{* * *}$ & 0.000 & $0.263^{* * *}$ & & & & & & \\
\hline Q8 & $0.739 * * *$ & 0.165 * & $0.270^{* * *}$ & $0.739 * * *$ & $0.228^{* * *}$ & $0.524^{* * *}$ & $0.612^{* * *}$ & $0.225^{* * *}$ & & & & & \\
\hline Q9 & $0.172^{* *}$ & 0.108 * & 0.100 & 0.172 ** & $0.233^{* * *}$ & 0.123 * & $0.176^{* *}$ & 0.063 & -0.092 & & & & \\
\hline Q10 & 0.020 & 0.078 & 0.053 & 0.020 & 0.000 & 0.078 & 0.029 & -0.083 & -0.028 & $0.421^{* * *}$ & & & \\
\hline Q11 \# & $1.000^{* * *}$ & $0.273^{* * *}$ & $0.390^{* * *}$ & $1.000^{* * *}$ & $0.445^{* * *}$ & $0.714^{* * *}$ & $0.879^{* * *}$ & $0.320^{* * *}$ & $0.739 * * *$ & $0.172^{* *}$ & 0.020 & & \\
\hline Q12 \# & $1.000^{* * *}$ & $0.273^{* * *}$ & $0.390^{* * *}$ & $1.000^{* * *}$ & $0.445^{* * *}$ & $0.714^{* * *}$ & $0.879^{* * *}$ & $0.320^{* * *}$ & $0.739 * * *$ & $0.172^{* *}$ & 0.020 & 1.000 & 1.000 \\
\hline
\end{tabular}

Registered microfinance institutions (MFI) $=1$, Refer to Table 1 for Questions 1-12. \# Variables with unitary correlations are not included in regressions. ${ }^{* * *}$ Significant at $p<0.001$,

** significant at $p<0.05, *$ significant at $p<0.10$ 
Table 3. Factor analysis $(\mathrm{N}=342)$.

\begin{tabular}{|c|c|c|c|}
\hline \multirow[b]{2}{*}{ Items } & \multicolumn{3}{|c|}{ Components } \\
\hline & $\begin{array}{l}\text { Personalized Info about } \\
\text { Savings/Loan Basics }\end{array}$ & $\begin{array}{l}\text { General Info } \\
\text { about Loans }\end{array}$ & $\begin{array}{l}\text { Knowledge of } \\
\text { Access to Savings }\end{array}$ \\
\hline Knowledge service charge & $\begin{array}{l}\text { Omitted-perfectly } \\
\text { predicts }\end{array}$ & & \\
\hline Knowledge interest rate & $\begin{array}{l}\text { Omitted-perfectly } \\
\text { predicts }\end{array}$ & & \\
\hline Knowledge savings interest & $\begin{array}{l}\text { Omitted-perfectly } \\
\text { predicts }\end{array}$ & & \\
\hline Receive promissory note & 0.893 & & \\
\hline Loan info from branch & 0.840 & & \\
\hline Knowledge about savings & 0.722 & & \\
\hline Maintain loan pass book & 0.676 & & \\
\hline Knowledge terms of loans & & 0.881 & \\
\hline Knowledge loan type & & 0.876 & \\
\hline $\begin{array}{l}\text { Knowledge of fees, premiums, } \\
\text { and claims for insurance services }\end{array}$ & & 0.692 & \\
\hline Knowledge withdrawing savings & & & 0.843 \\
\hline Knowledge voluntary savings & & & 0.809 \\
\hline
\end{tabular}

Table 4 reports descriptive statistics and tests of difference for demographic variables for clients of registered and unregistered MFIs and the factor scores. The mean annual income was 42,611 taka, with a significant difference $(p<0.000)$ between the mean for 200 registered NGO-MFI clients $(53,724$ taka) and that for 142 clients of unregistered NGO-MFIs (27,592 taka). The factor score for Factor 1 "Knowledge about personalized information about savings/loan basics" for the full sample was -0.018 , with a significant difference $(p<0.000)$ between the means for registered $(0.801)$ and unregistered $(-1.171)$ NGO-MFI clients. For Factor 2, "General knowledge about savings/loan", the overall mean was -0.037 , with a significant difference $(p<0.000)$ between means for registered $(0.275)$ and unregistered MFI clients (-0.475). For Factor 3, "Knowledge of access to savings", overall, the mean was -0.004 , with an insignificant difference between means for registered and unregistered NGO-MFI clients.

The mean age of clients was 39.9 years, with no significant difference for clients of registered versus unregistered NGO-MFIs. The mean number of children was 4.5 overall, with means of 3.7 and 5.7 for registered and unregistered MFI clients, respectively, which is a significant difference $(p<0.000)$.

For the dichotomous variables, overall 59 percent of clients were married, with a significant difference $(p<0.01)$ for clients of registered (50 percent) and unregistered (70 percent) NGO-MFIs. In terms of microenterprise ownership, 66 percent overall owned a microenterprise, at 83 and 42 percent for registered and unregistered MFIs, respectively, a difference that is significant $(p<0.000)$. In terms of education, there was a significant difference $(p<0.000)$ between clients of the two types of MFI: 77 and 33 percent of clients of registered and unregistered NGO-MFIs, respectively, had some schooling. 
Table 4. Descriptive statistics.

\begin{tabular}{|c|c|c|c|c|c|c|c|c|c|c|}
\hline \multirow{3}{*}{$\begin{array}{c}\text { Variables } \\
\text { Continuous }\end{array}$} & \multirow{2}{*}{\multicolumn{2}{|c|}{$\begin{array}{c}\text { All MFIs } \\
\mathrm{N}=342 \\
\end{array}$}} & \multirow{2}{*}{\multicolumn{2}{|c|}{$\begin{array}{c}\text { Registered MFIs } \\
\mathrm{N}=200(58.5 \%)\end{array}$}} & \multirow{2}{*}{\multicolumn{5}{|c|}{$\begin{array}{c}\text { Unregistered MFIs } \\
\mathrm{N}=142(41.5 \%)\end{array}$}} & \multirow[b]{3}{*}{$\begin{array}{c}\text { Independent } \\
\text { Samples } t \text {-Tes }\end{array}$} \\
\hline & & & & & & & & & & \\
\hline & Mean & Mean & Std. Dev. & Min & Max & Mean & Std. Dev. & Min & Max & \\
\hline Annual income (taka) & 42,611 & 53,724 & 18,611 & 5400 & 114,000 & 27,592 & 11,441 & 6000 & 78,000 & $-14.598^{* * *}$ \\
\hline Fac1-Personalized info about savings/loan basics & 0.000 & 0.717 & 0.576 & -0.555 & 1.249 & -1.010 & 0.439 & -1.711 & 0.360 & $-30.055^{* * *}$ \\
\hline Fac2-General info about Loans & 0.000 & 0.273 & 1.191 & -0.997 & 2.099 & -0.385 & 0.403 & -0.755 & 0.307 & $-6.332 * * *$ \\
\hline Fac3-Knowledge of access to savings & 0.000 & 0.016 & 0.562 & -1.731 & 0.659 & -0.022 & 1.404 & -5.826 & 0.688 & -0.347 \\
\hline Client age & 39.892 & 38.955 & 13.967 & 16.000 & 86.000 & 41.211 & 11.966 & 21.000 & 79.000 & 1.561 \\
\hline Number of children & 4.538 & 3.715 & 2.405 & 0 & 13 & 5.697 & 2.173 & 0 & 10 & $7.814^{* * *}$ \\
\hline Dichotomous & & & & & & & & & & $\mathrm{Chi}^{2}$ \\
\hline Married $(1=$ yes, $0=$ no $)$ & $59.1 \%$ & $51.5 \%$ & & 0 & 1 & $69.7 \%$ & & 0 & 1 & $11.399 * *$ \\
\hline Microenterprise $(1=$ yes, $0=$ no $)$ & $65.5 \%$ & $82.5 \%$ & & 0 & 1 & $41.5 \%$ & & 0 & 1 & $61.622 * * *$ \\
\hline Education $(1=$ yes, $0=$ no $)$ & $58.8 \%$ & $77.0 \%$ & & 0 & 1 & $33.1 \%$ & & 0 & 1 & $66.052 * * *$ \\
\hline
\end{tabular}

Fac1 = Score-Personalized info about savings/loan basics; Fac2 = Score-General information about loans; Fac3 = Score-Knowledge of access to savings; MFI Status = Client membership of registered or unregistered MFI (coded yes = 1, otherwise 0); Age = Client age; Children = Self-declared number of clients' children; Married-coded yes = 1, otherwise 0; Microenterprise $p<0.05$. 


\subsection{Pearson's Correlations}

Table 5 reports the Pearson's correlations for the 342 client observations between registered and unregistered NGO-MFI members' financial literacy as represented by the factor scores, as well as income, age, number of children, and education level. There were significant positive correlations between the three factors [Factor 1 "Knowledge about personalized information about savings/loan basics", Factor 2, "General knowledge about savings/loan" and Factor 3, "Knowledge of access to savings"] $(r=0.969, r=0.376$, and $r=0.069$, respectively) and the status (registered/unregistered) of their NGO-MFIs. It is important to note that Factor 1, "Knowledge of personalized information about loan/savings", was almost perfectly correlated with registered MFI status, and it is likely that this lack of variability will cause problems with multivariate estimation. None of the correlations between the three factors themselves was higher than 0.240 .

Strong positive correlations were noted between NGO-MFI status and clients' number of children, education, and microenterprise ownership. Client income was significantly correlated with the three factors $(r=0.539, r=0.266$, and $r=0.145$, respectively), and also with NGO-MFI status $(r=0.638)$. In terms of independent variables, client age, as is to be expected, was highly correlated $(r=0.660)$ with the number of children and with education $(r=0.425)$. None of the other correlations between the independent variables was higher than 0.400 , and so should not present multicollinearity concerns.

\subsection{Multivariate Results}

OLS Regression results for the test of Hypothesis 1 are reported in Table 6. This test regressed the hypothesis and control variables on each of the factor scores and the total factor score. The F statistics for all three models were significant, and the $\mathrm{R}^{2}$ ranged from 75 percent for Factor 1 , to 15 percent for Factor 2, and only 3 percent for Factor 3. For the total factor score as the dependent variable, the $\mathrm{R}^{2}$ was 50 percent. The regressions were robust, controlling for client observations attached to the same NGO-MFI. Notably, MFI status (registered/unregistered) was highly significant $(p<0.001)$ and positive for Factors 1 and 2 and the total factor score. That is, client financial literacy and awareness were higher for registered MFIs compared with unregistered MFIs controlling for education and microenterprise ownership. Hence, Hypothesis 1 was supported. Having some schooling (education) was significant $(p<0.001)$ only for Factor 2 . Client ownership of microenterprises was significant $(p<0.01)$ in explaining all three factors and their total $(p<0.05)$, but was negatively significant for Factor 2 .

For the tests of Hypothesis 2 and Hypothesis 3, robust OLS regression was used, with results reported in Table 7 . Total factor score was used, due to the high correlation between registered NGO-MFI client membership and Factor 1 scores $^{8}$. Again, the robust regression fit well, with significant F statistics and with a model $\mathrm{R}^{2}$ of 45 percent. The total factor score was significant $(p<0.01)$, supporting Hypothesis 2, as was belonging to a registered NGO-MFI $(p<0.001)$, thus supporting Hypothesis 3 . Amongst the control variables, the number of children alone was significant $(p<0.05)$ and positive, indicating that children in this setting, on average, add to family income rather than detract from it. Age was negative but not significant, and, hence, this direction needs to be interpreted with caution.

8 When the three factor scores are included as variables in their own right rather than as a total in the regression, the highest variance inflation factor is over 6 , and when the omitted items from the factor analysis are not excluded, it increases to over 30 . 
Table 5. Pearson's correlations $(\mathrm{N}=342)$.

\begin{tabular}{|c|c|c|c|c|c|c|c|c|c|c|}
\hline Variables & $\begin{array}{l}\text { MFI Status } \\
\text { Registered }\end{array}$ & Factor 1 & Factor 2 & Factor 3 & Factor Total & Age & Education & Married & Children & Micro-Enterprise \\
\hline Factor 1 & $0.852 * * *$ & & & & & & & & & \\
\hline Factor 2 & $0.325^{* * *}$ & 0.000 & & & & & & & & \\
\hline Factor 3 & 0.019 & 0.000 & 0.000 & & & & & & & \\
\hline Factor Tot & $0.691^{* * *}$ & $0.577^{* * *}$ & $0.577^{* * *}$ & $0.577^{* * *}$ & & & & & & \\
\hline Age & -0.084 & 0.076 & $-0.242^{* * *}$ & 0.079 & -0.050 & & & & & \\
\hline Education & $0.440 * * *$ & $0.390^{* * *}$ & $0.307^{* * *}$ & -0.019 & $0.392^{* * *}$ & $-0.425^{* * *}$ & & & & \\
\hline Married & $-0.183^{* *}$ & $-0.236^{* * *}$ & 0.070 & 0.062 & -0.061 & $-0.237^{* * *}$ & $0.148^{* *}$ & & & \\
\hline Children & $-0.390 * * *$ & $-0.270 * * *$ & $-0.271^{* * *}$ & $0.110^{*}$ & $-0.249^{* * *}$ & $0.660 * * *$ & $-0.390 * * *$ & -0.061 & & \\
\hline Microenterprise & $0.425^{* * *}$ & $0.519^{* * *}$ & 0.053 & $0.140 *$ & $0.411^{* * *}$ & -0.018 & $0.267^{* * *}$ & $-0.141^{* *}$ & $-0.173^{* *}$ & \\
\hline Financial status & $0.638^{* * *}$ & $0.539 * * *$ & $0.266^{* * *}$ & $0.145^{* *}$ & $0.549 * * *$ & -0.057 & $0.342 * * *$ & -0.036 & $-0.179 * *$ & $0.314^{* * *}$ \\
\hline
\end{tabular}

MFI Status = Client membership of registered or unregistered MFIs (coded yes = 1, otherwise 0); Fac1 = Score-Personalized info about savings/loan basics; Fac2 = Score-General information about Loans; Fac3 = Knowledge of access to savings; Age = Client age; Education = Client has some schooling (coded yes $=1$, otherwise 0); Children $=$ Self-declared number of at $p<0.01 ;{ }^{*}$ significant at $p<0.05$.

Table 6. Ordinary least squares (OLS) regression with dependent variable client financial literacy factors (Hypothesis 1).

\begin{tabular}{|c|c|c|c|c|c|c|c|c|c|c|c|c|}
\hline \multirow{3}{*}{$\begin{array}{l}\text { Dependent } \\
\text { Variables }\end{array}$} & \multicolumn{3}{|c|}{ Panel A-Factor 1 Score } & \multicolumn{3}{|c|}{ Panel B-Factor 2 Score } & \multicolumn{3}{|c|}{ Panel C-Factor 3 Score } & \multicolumn{3}{|c|}{ Total Factor Score } \\
\hline & \multicolumn{3}{|c|}{$\begin{array}{l}\text { Personalized info about } \\
\text { Savings/Loan Basics }\end{array}$} & \multicolumn{3}{|c|}{ General info about Loans } & \multicolumn{3}{|c|}{ Knowledge of Access to Savings } & \multicolumn{3}{|c|}{ Client Financial Literacy } \\
\hline & Coef. & Std. Err. & $t, P>t$ & Coef. & Std. Err. & $t, P>t$ & Coef. & Std. Err. & $\mathrm{T}, \mathrm{P}>\mathrm{t}$ & Coef. & Std. Err. & $\mathrm{T}, \mathrm{P}>\mathrm{t}$ \\
\hline Registered & 1.562 & 0.074 & $21.16^{* * *}$ & 0.573 & 0.107 & $5.34 * * *$ & -0.059 & 0.127 & -0.47 & 2.075 & 0.148 & $14.04^{* * *}$ \\
\hline Education & 0.001 & 0.067 & 0.01 & 0.438 & 0.115 & $3.81 * * *$ & -0.102 & 0.142 & -0.72 & 0.336 & 0.177 & 1.90 \\
\hline Microenterprise & 0.403 & 0.078 & $5.18^{* * *}$ & -0.261 & 0.096 & $-2.72 * *$ & 0.348 & 0.117 & $2.96 * *$ & 0.491 & 0.146 & $3.36^{* *}$ \\
\hline _cons & -1.178 & 0.058 & $-20.31^{* * *}$ & -0.422 & 0.062 & $-6.76^{* * *}$ & -0.133 & 0.145 & -0.992 & -1.732 & 0.161 & $-10.77^{* * *}$ \\
\hline F Stat & & $296.56^{* * *}$ & & & $18.21^{* * *}$ & & & $8.27^{* * *}$ & & & $120.63^{* * *}$ & \\
\hline $\mathrm{R} 2$ & & 0.757 & & & 0.154 & & & 0.024 & & & 0.501 & \\
\hline Root MSE & & 0.495 & & & 0.925 & & & 0.993 & & & 1.229 & \\
\hline $\mathrm{N}$ & & 342 & & & 342 & & & 342 & & & 342 & \\
\hline No. of Clusters & & 147 & & & 147 & & & 147 & & & 147 & \\
\hline
\end{tabular}

Fac1 = Score-Personalized info about savings/loan basics; Fac2 = Score-General information about loans; Fac3 = Score-Knowledge of access to savings; MFI Status = Client membership of registered or unregistered MFI (coded yes = 1, otherwise 0 ); Age = Client age; Children = Self-declared number of children; Microent $=$ Self-declared microenterprise exists (coded yes = 1 , otherwise 0$)$; Education = Client has some schooling (coded yes $=1$, otherwise 0$) .{ }^{* * *}=$ Significant at $p<0.001$; ${ }^{* *}$ significant at $p<0.01$. 
Table 7. OLS regression with dependent variable financial status (Hypothesis 2 and Hypothesis 3) $(\mathrm{N}=342)$.

\begin{tabular}{|c|c|c|c|}
\hline Dependent Variable: LnIncome & Coef. & Robust Std. Err & $\mathbf{t} \mathbf{P}>|\mathbf{t}|$ \\
\hline Financial Literacy (total factor score) & 0.054 & 0.019 & $2.820 * *$ \\
\hline Registered & 0.574 & 0.075 & $7.620 * * *$ \\
\hline Age & -0.003 & 0.003 & -0.940 \\
\hline Married & 0.070 & 0.043 & 1.630 \\
\hline No. Children & 0.031 & 0.013 & $2.430 * *$ \\
\hline Education & 0.047 & 0.054 & 0.880 \\
\hline Microenterprise & 0.033 & 0.047 & 0.690 \\
\hline _cons & 10.072 & 0.099 & $101.360^{* * *}$ \\
\hline$F(9,146)$ & \multicolumn{3}{|c|}{$38.73^{* * *}$} \\
\hline $\mathrm{R}^{2}$ & \multicolumn{3}{|c|}{0.446} \\
\hline $\mathrm{N}$ & \multicolumn{3}{|c|}{342} \\
\hline Number of clusters & \multicolumn{3}{|c|}{147} \\
\hline Highest VIF & \multicolumn{3}{|c|}{2.40 without robust } \\
\hline
\end{tabular}

Financial Status = Natural log of self-declared client annual income (taka); Total Factor Score = Sum of Fac1 (score-personalized info about savings/loan basics) + Fac2 (score-general information about loans) + Fac3 (score - knowledge of access to savings); MFI Status = Client membership of registered or unregistered MFI (coded registered yes $=1$, otherwise 0); Age = Client age; Married = Client's marital status (coded 1 if married, 0 if separated, widowed, divorced, or single); Children $=$ Self-declared number of children; Microenterprise $=$ Self-declared microenterprise exists (coded yes $=1$, otherwise 0$).$ VIF $=$ Variance inflation factor. ${ }^{* * *}$ Significant at $p<0.001$; ** significant at $p<0.01$.

\subsection{Robustness Tests}

As a robustness test for Hypothesis 1, a financial literacy index comprising the questions listed in Table 1 with clients' yes responses were used to create a score between 0-12 and analyzed using truncated regression for the same client sample. That is, instead of factor analyzing, each question was equally weighted and the total of yes responses is used as the dependent variable that is truncated at a maximum score of 12 . The mean score for the full sample is 7.01 with that for the regulated MFIs is 9.725 and for unregulated NGO-MFIs is 3.20, a difference that is significant at $p<0.001$. The untabulated truncated regression results based on 342 observations clustered on NGO-MFI identity confirm (refer Table 6) the factor analysis results. The model fits well with an $\mathrm{R}^{2}$ of 38.52 per cent. The registered MFI indicator was significant at $p<0.001$, consistent with the total factor score as the dependent variable analysis. The variable representing clients with some schooling was significant at $p<0.001$ and microenterprise ownership was significant at $p<0.05$.

Similarly, the same financial literacy index was used as a robustness test for Hypothesis 2 and Hypothesis 3 with income as the dependent variable. The OLS results confirmed (refer Table 7 ) the significance of the financial literacy index $(p<0.01)$ and registered NGO-MFI indicator $(p<0.05)$ in explaining client income, with an $\mathrm{R}^{2}$ of 43.33 per cent. No other variables were significant. Both of these results confirm the primary findings.

\section{Discussion and Conclusions}

In many countries, consumer protection in financial services is shared among multiple financial and nonfinancial regulators and enforcement bodies (Brix and McKee 2010). However, regulation alone cannot protect the interests of consumers and enhance consumer awareness and prevent market misconduct (Brix and McKee 2010; Beltran 2007). Self-regulatory initiatives, consumer awareness, and financial literacy programs can play a vital role.

Solli et al. (2011) claimed that the planning process for a new regulatory regime should require attention to consumer awareness and rights and knowledge about financial products. Hence, microfinance regulation, especially concerning client protection, is critical to achieving the social objectives of a microfinance program. Brix and McKee (2010) emphasized the need for regulation in countries where microfinance is growing rapidly, and unregulated microfinance has come under 
critical scrutiny in the press, due to coverage of over-indebtedness by MFI borrowers. Clients should understand their rights and entitlements from the relevant financial institution (Beltran 2007).

The importance of regulation in the financial knowledge and awareness of MFI clients (of both nonprofit and commercial MFIs) can be inferred from this study. This importance is relevant for conventional banking contexts in developed economies (e.g., (Lee et al. 2019)) and so the result from this study in a microfinance and developing economy context is not surprising; however, it is rare for this issue to be examined in a microcredit context. From the results, we can conclude that the regulation and appropriate guidelines for MFIs' conduct can play a significant role in increasing their clients' financial literacy and awareness of their rights. Furthermore, this higher knowledge and awareness is positively associated with clients' financial intermediation. This study implies that the planning process for reforms in a microfinance context should focus on how to increase consumer awareness and financial capability, particularly for women, rather than focusing only on the regulatory function of the process.

Having knowledge about weekly loan payments alone cannot be considered as sound financial literacy or awareness by clients. Access to more complex products, such as insurance, and understanding of interest require a higher level of awareness. With knowledge of the loan, the interest rate, savings, and insurance, clients should have the capability to budget in order to repay in installments. According to Tiwari et al. (2008), financial literacy training should not only aim for a change in levels of knowledge about financial products, but also a behavioral change. During financial training, clients should be given information by their MFIs that they are able to understand and use. Furthermore, while not an issue for this study, technology-oriented services are increasingly presenting a cyber and money laundering risk, which requires greater sophistication in the education of both MFI personnel and their clients (Shinozaki et al. 2017).

These findings lead to the conclusion that economists, social scientists, policymakers, governments, and development agencies should make pragmatic efforts to increase the knowledge and awareness of MFI clients. Further, these pragmatic efforts should especially focus on women since women are the best recipients of microfinance (Lee et al. 2019). This should be one of the key focus points for the overall planning process for any reform of regulation. However, in spite of the evidence presented of positive outcomes for clients of regulated NGO-MFIs, our study indicated that some clients prefer unregistered nonprofit NGO-MFIs over registered NGO-MFIs as their financial institutions. An important observation from interview evidence gathered for a wider study revealed that the most vulnerable and poor borrowers tend to be served by unregistered NGO-MFIs. An executive of an unregulated NGO-MFI provided one rationale for this:

"Loan defaulters from other large MFIs and overlapping customers who are disqualified from all registered MFIs are the poorest segment of clients. They do not have any source for accessing credit. As a result, many of them engage themselves with destructive activities like social crimes and domestic violence and become a burden on society. We support these types of clients by providing them training and education and giving them loans so that they can regain their confidence and become valuable citizens of the country". (MFI No. 133)

It is, therefore, important to note that the outreach of MFIs does not necessarily bring the welfare of MFI clients to the fore, ostensibly the primary goal of microfinance. Previous research has also found gaps between the goals of MFIs and unlawful and inappropriate pressure, violence, and abuse of clients by loan collectors and MFI borrowing group members (Banerjee and Jackson 2017; Bateman 2012; Maittrot 2018). Microfinance practice needs to be understood in the context of the totality of the social, economic, and other financial structures that control the life of the poor (Dattasharma et al. 2016).

The double bottom-line goal of microfinance can be better achieved by ensuring strong monitoring of MFIs and discouraging any type of malpractice by MFI staff in their dealings with clients. This study's results imply that the welfare of MFI clients can be achieved not only through appropriate monitoring and guidance, but also through a focus on increasing consumer awareness and financial capability. 
To generalize the findings from this study, similar research would need to target the microfinance sector in other countries. A randomized control study of client financial knowledge and awareness before and after regulatory reforms in the microfinance sector would be needed before causation can be attributed. However, this study found a strong association between NGO-MFI clients' consumer protection knowledge and client financial status. Whether the clients of registered MFIs had this greater knowledge before becoming members or gained their knowledge from other MFIs cannot be discerned.

This study has several limitations. The number of clients questioned for each MFI was small and these clients may differ in their characteristics from other clients. The number of MFIs, particularly unregulated MFIs, is also relatively small but adequate for the model applied. Future research could expand on the sample size for both clients and MFIs and examine financial literacy in other contexts to investigate what other institutional settings might influence knowledge of this type.

In terms of future research, examining interventions by MFIs or other organizations that provide both language and numeracy training could be examined, since it could be that unregistered MFIs do not require the same level of document completion by clients, which makes them attractive to those with low levels of general literacy.

Author Contributions: Conceptualization, Z.M., C.J., and M.H.; methodology, Z.M., and C.J.; validation, Z.M.; formal analysis, C.J. and Z.M.; investigation, Z.M.; resources, M.H., and Z.M.; writing-original draft preparation, Z.M.; writing-review and editing, C.J., Z.M., and M.H.; visualization, C.J., Z.M., and M.H. All authors have read and agreed to the published version of the manuscript.

Funding: This research received no external funding.

Acknowledgments: The authors thank the MFI executives and their clients for their valuable feedback and comments, and remarks which improved the paper.

Conflicts of Interest: The authors declare no conflict of interest. The MFI executives and their clients had no role/interest in the design of the study; in the collection, analyses, or interpretation of data; in the writing of the manuscript, or in the decision to publish the results.

\section{Appendix A}

Table A1. Inverse of Correlation Matrix $(\mathrm{N}=342)$.

\begin{tabular}{cccccccccc}
\hline & Q6 & Q5 & Q8 & Q4 & Q2 & Q1 & Q7 & Q9 & Q10 \\
\hline Q6 & 2.684 & -1.275 & -0.803 & -0.218 & -0.072 & -0.520 & -0.196 & -0.334 & 0.170 \\
Q5 & -1.275 & 2.750 & -0.717 & -0.889 & 0.487 & 0.268 & 0.351 & 0.024 & -0.226 \\
Q8 & -0.803 & -0.717 & 1.965 & 0.328 & -0.441 & 0.140 & -0.186 & 0.387 & -0.033 \\
Q4 & -0.218 & -0.889 & 0.328 & 1.736 & -0.532 & 0.439 & -0.324 & -0.271 & 0.166 \\
Q2 & -0.072 & 0.487 & -0.441 & -0.532 & 2.452 & -1.467 & -0.317 & 0.011 & -0.093 \\
Q1 & -0.520 & 0.268 & 0.140 & 0.439 & -1.467 & 2.293 & -0.240 & -0.080 & -0.091 \\
Q7 & -0.196 & 0.351 & -0.186 & -0.324 & -0.317 & -0.240 & 1.428 & -0.045 & 0.146 \\
Q9 & -0.334 & 0.024 & 0.387 & -0.271 & 0.011 & -0.080 & -0.045 & 1.406 & -0.572 \\
Q10 & 0.170 & -0.226 & -0.033 & 0.166 & -0.093 & -0.091 & 0.146 & -0.572 & 1.277
\end{tabular}

Q1 Do you know the types of loans and other facilities available from your MFI?, Q2 Did loan officers/lenders explain to you the terms and conditions of the loan?, Q3 Do you know the interest rate (per month) on your loan and savings charged by and paid by your MFI?, Q4 Do you maintain any loan or savings passbook given by your MFI?, Q5 Do loan officers/lenders give you a copy of the promissory note for your records?, Q6 Can you get information about your loan and savings from your branch office any working day?, Q7 Do you know about the fees, premium, and settlement of claim of your insurance service?, Q9 Can you withdraw your savings (partially or fully) from your MFI (if your loan is cleared)?, Q10 Do you have any other voluntary savings in your MFI? 
Table A2. Anti-image Matrices $(\mathrm{N}=342)$.

\begin{tabular}{|c|c|c|c|c|c|c|c|c|c|c|}
\hline & & Q6 & Q5 & Q8 & Q4 & Q2 & Q1 & Q7 & Q9 & Q10 \\
\hline \multirow{9}{*}{$\begin{array}{l}\text { Anti-image } \\
\text { Covariance }\end{array}$} & Q6 & 0.373 & -0.173 & -0.152 & -0.047 & -0.011 & -0.085 & -0.051 & -0.088 & 0.050 \\
\hline & Q5 & -0.173 & 0.364 & -0.133 & -0.186 & 0.072 & 0.042 & 0.089 & 0.006 & -0.064 \\
\hline & Q8 & -0.152 & -0.133 & 0.509 & 0.096 & -0.091 & 0.031 & -0.066 & 0.140 & -0.013 \\
\hline & $\mathrm{Q} 4$ & -0.047 & -0.186 & 0.096 & 0.576 & -0.125 & 0.110 & -0.131 & -0.111 & 0.075 \\
\hline & Q2 & -0.011 & 0.072 & -0.091 & -0.125 & 0.408 & -0.261 & -0.090 & 0.003 & -0.030 \\
\hline & Q1 & -0.085 & 0.042 & 0.031 & 0.110 & -0.261 & 0.436 & -0.073 & -0.025 & -0.031 \\
\hline & Q7 & -0.051 & 0.089 & -0.066 & -0.131 & -0.090 & -0.073 & 0.700 & -0.022 & 0.080 \\
\hline & Q9 & -0.088 & 0.006 & 0.140 & -0.111 & 0.003 & -0.025 & -0.022 & 0.711 & -0.319 \\
\hline & Q10 & 0.050 & -0.064 & -0.013 & 0.075 & -0.030 & -0.031 & 0.080 & -0.319 & 0.783 \\
\hline \multirow{9}{*}{$\begin{array}{l}\text { Anti-image } \\
\text { Correlation }\end{array}$} & Q6 & $0.738^{a}$ & -0.469 & -0.349 & -0.101 & -0.028 & -0.210 & -0.100 & -0.172 & 0.092 \\
\hline & Q5 & -0.469 & $0.641^{\mathrm{a}}$ & -0.308 & -0.407 & 0.187 & 0.107 & 0.177 & 0.012 & -0.121 \\
\hline & Q8 & -0.349 & -0.308 & $0.705^{a}$ & 0.177 & -0.201 & 0.066 & -0.111 & 0.233 & -0.021 \\
\hline & Q4 & -0.101 & -0.407 & 0.177 & $0.624^{\mathrm{a}}$ & -0.258 & 0.220 & -0.206 & -0.174 & 0.111 \\
\hline & Q2 & -0.028 & 0.187 & -0.201 & -0.258 & $0.624^{\mathrm{a}}$ & -0.618 & -0.169 & 0.006 & -0.053 \\
\hline & Q1 & -0.210 & 0.107 & 0.066 & 0.220 & -0.618 & $0.604^{\mathrm{a}}$ & -0.132 & -0.044 & -0.053 \\
\hline & Q7 & -0.100 & 0.177 & -0.111 & -0.206 & -0.169 & -0.132 & $0.784^{\mathrm{a}}$ & -0.032 & 0.108 \\
\hline & Q9 & -0.172 & 0.012 & 0.233 & -0.174 & 0.006 & -0.044 & -0.032 & $0.510^{\mathrm{a}}$ & -0.427 \\
\hline & Q10 & 0.092 & -0.121 & -0.021 & 0.111 & -0.053 & -0.053 & 0.108 & -0.427 & $0.461^{\mathrm{a}}$ \\
\hline
\end{tabular}

${ }^{\mathrm{a}}$ Measures of Sampling Adequacy (MSA). Refer to Table A1 for question content.

Table A3. KMO and Bartlett's Test.

\begin{tabular}{llc}
\hline Kaiser-Meyer-Olkin Measure of Sampling Adequacy. & 0.651 \\
\hline \multirow{3}{*}{ Bartlett's Test of Sphericity } & Approx. Chi-Square & 1106.189 \\
& df & 36 \\
& Sig. & 0.000 \\
\hline
\end{tabular}

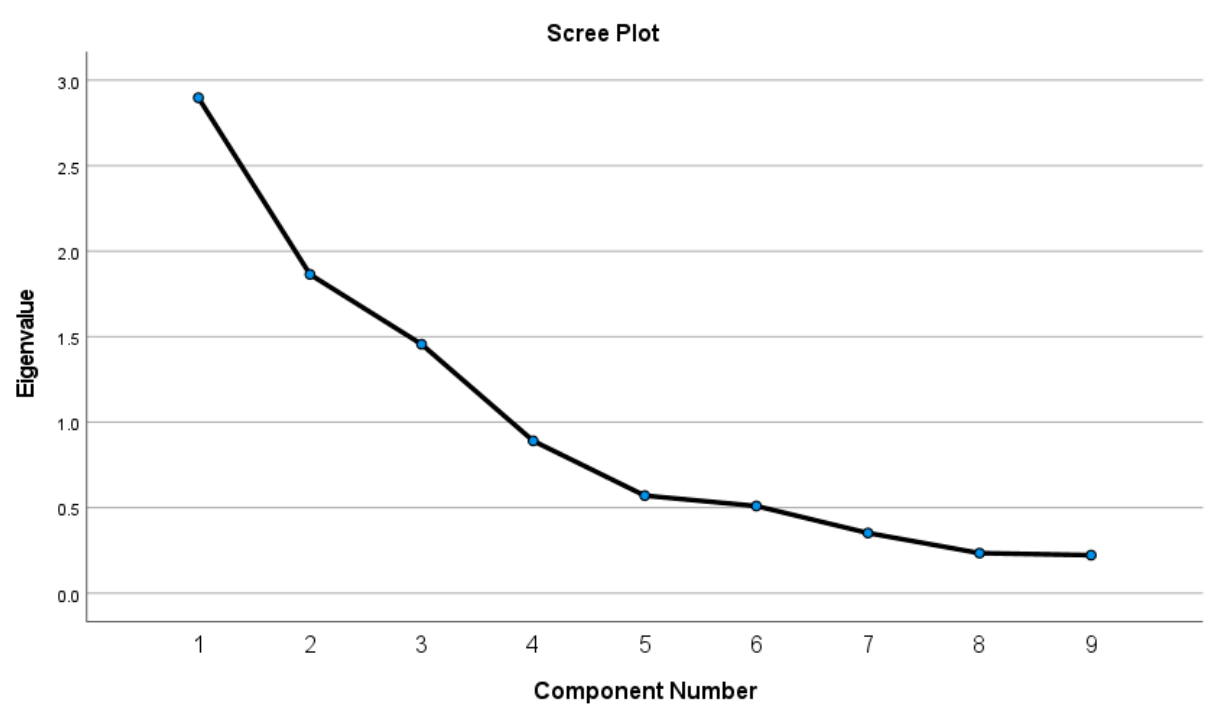

Figure A1. Scree Plot. 
Table A4. Communalities.

\begin{tabular}{cc}
\hline & Extraction \\
\hline Q6 & 0.776 \\
Q5 & 0.840 \\
Q8 & 0.631 \\
Q4 & 0.495 \\
Q2 & 0.792 \\
Q1 & 0.775 \\
Q7 & 0.520 \\
Q9 & 0.734 \\
Q10 & 0.654
\end{tabular}

Extraction Method: Principal Component Analysis. Refer to Table A1 for question content.

Table A5. Total Variance Explained.

\begin{tabular}{|c|c|c|c|c|c|c|c|}
\hline \multirow{2}{*}{ Component } & \multicolumn{3}{|c|}{ Initial Eigenvalues } & \multicolumn{3}{|c|}{$\begin{array}{c}\text { Extraction Sums of Squared } \\
\text { Loadings }\end{array}$} & \multirow{2}{*}{$\begin{array}{c}\begin{array}{c}\text { Rotation } \\
\text { Sums of } \\
\text { Squared } \\
\text { Loadings }\end{array} \\
\text { Total }\end{array}$} \\
\hline & Total & $\begin{array}{c}\% \text { of } \\
\text { Variance }\end{array}$ & $\underset{\%}{\text { Cumulative }}$ & Total & $\begin{array}{c}\% \text { of } \\
\text { Variance }\end{array}$ & $\underset{\%}{\text { Cumulative }}$ & \\
\hline 1 & 2.897 & 32.194 & 32.194 & 2.897 & 32.194 & 32.194 & 2.635 \\
\hline 2 & 1.865 & 20.718 & 52.912 & 1.865 & 20.718 & 52.912 & 2.287 \\
\hline 3 & 1.456 & 16.177 & 69.089 & 1.456 & 16.177 & 69.089 & 1.491 \\
\hline 4 & 0.891 & 9.902 & 78.991 & & & & \\
\hline 5 & 0.571 & 6.344 & 85.335 & & & & \\
\hline 6 & 0.510 & 5.669 & 91.003 & & & & \\
\hline 7 & 0.352 & 3.915 & 94.918 & & & & \\
\hline 8 & 0.235 & 2.607 & 97.525 & & & & \\
\hline 9 & 0.223 & 2.475 & 100.000 & & & & \\
\hline
\end{tabular}

Extraction Method: Principal Component Analysis. ${ }^{a}$ When components are correlated, sums of squared loadings cannot be added to obtain a total variance. See Table A1 for question content.

Table A6. Component Matrix ${ }^{\text {a }}$.

\begin{tabular}{cccc}
\hline & \multicolumn{3}{c}{ Component } \\
\cline { 2 - 4 } & $\mathbf{1}$ & $\mathbf{2}$ & $\mathbf{3}$ \\
\hline Q6 & 0.838 & -0.264 & \\
Q8 & 0.694 & -0.207 & -0.327 \\
Q4 & 0.610 & -0.337 & \\
Q7 & 0.527 & 0.471 & \\
Q1 & 0.480 & 0.736 & \\
Q5 & 0.632 & -0.664 & \\
Q2 & 0.598 & 0.659 & \\
Q9 & 0.258 & & 0.817 \\
Q10 & & & 0.803 \\
\hline
\end{tabular}

Extraction Method: Principal Component Analysis. ${ }^{\text {a }} 3$ components extracted. See Table A1 for question content. 
Table A7. Reproduced Correlations.

\begin{tabular}{ccccccccccc}
\hline & & Q6 & Q5 & Q8 & Q4 & Q2 & Q1 & Q7 & Q9 & Q10 \\
\hline \multirow{5}{*}{ Reproduced } & Q6 & $0.776^{\mathrm{a}}$ & 0.706 & 0.657 & 0.594 & 0.328 & 0.205 & 0.327 & 0.169 & 0.034 \\
& Q5 & 0.706 & $0.840^{\mathrm{a}}$ & 0.580 & 0.608 & -0.059 & -0.186 & 0.023 & 0.164 & 0.058 \\
& Q8 & 0.657 & 0.580 & $0.631^{\mathrm{a}}$ & 0.462 & 0.280 & 0.166 & 0.316 & -0.084 & -0.192 \\
& Q2 & 0.328 & -0.608 & 0.462 & $0.495^{\mathrm{a}}$ & 0.143 & 0.049 & 0.149 & 0.242 & 0.140 \\
& Q1 & 0.205 & -0.186 & 0.280 & 0.143 & $0.792^{\mathrm{a}}$ & 0.772 & 0.626 & 0.139 & 0.050 \\
& Q7 & 0.327 & 0.023 & 0.316 & 0.149 & 0.626 & 0.593 & $0.520^{\mathrm{a}}$ & 0.007 & -0.071 \\
& Q9 & 0.169 & 0.164 & -0.084 & 0.242 & 0.139 & 0.147 & 0.007 & $0.734^{\mathrm{a}}$ & 0.682 \\
& Q10 & 0.034 & 0.058 & -0.192 & 0.140 & 0.050 & 0.076 & -0.071 & 0.682 & $0.654^{\mathrm{a}}$ \\
\hline \multirow{5}{*}{ Residual $^{\mathrm{b}}$} & Q6 & & -0.045 & -0.045 & -0.146 & -0.042 & 0.039 & -0.064 & 0.007 & -0.005 \\
& Q5 & -0.045 & & -0.056 & -0.082 & 0.021 & 0.070 & -0.023 & -0.042 & 0.020 \\
& Q8 & -0.045 & -0.056 & & -0.234 & -0.010 & -0.001 & -0.092 & -0.007 & 0.164 \\
& Q4 & -0.146 & -0.082 & -0.234 & & 0.047 & -0.060 & 0.087 & -0.009 & -0.140 \\
& Q2 & -0.042 & 0.021 & -0.010 & 0.047 & & -0.062 & -0.160 & -0.040 & 0.003 \\
& Q1 & 0.039 & 0.070 & -0.001 & -0.060 & -0.062 & & -0.191 & -0.038 & 0.002 \\
& Q7 & -0.064 & -0.023 & -0.092 & 0.087 & -0.160 & -0.191 & & 0.056 & -0.013 \\
& Q9 & 0.007 & -0.042 & -0.007 & -0.009 & -0.040 & -0.038 & 0.056 & & -0.260 \\
& Q10 & -0.005 & 0.020 & 0.164 & -0.140 & 0.003 & 0.002 & -0.013 & -0.260 & \\
\hline
\end{tabular}

Extraction Method: Principal Component Analysis. ${ }^{a}$ Reproduced communalities; ${ }^{b}$ Residuals are computed between observed and reproduced correlations. There are $16(44.0 \%)$ nonredundant residuals with absolute values greater than 0.05 . See Table A1 for question content.

Table A8. Structure Matrix.

\begin{tabular}{cccc}
\hline & \multicolumn{3}{c}{ Component } \\
\cline { 2 - 4 } & $\mathbf{1}$ & $\mathbf{2}$ & $\mathbf{3}$ \\
\hline Q5 & 0.875 & & \\
Q6 & 0.861 & 0.340 & \\
Q8 & 0.733 & 0.310 & -0.209 \\
Q4 & 0.685 & & \\
Q2 & & 0.887 & \\
Q1 & & 0.867 & \\
Q7 & 0.238 & 0.708 & \\
Q9 & & & 0.847 \\
Q10 & & & 0.808 \\
\hline
\end{tabular}

Extraction Method: Principal Component Analysis. Rotation Method: Oblimin with Kaiser Normalization. See Table A1 for question content.

\section{References}

Ahmed, Md. Kabir. 2013. Regulation and Supervision of MFIs in Bangladesh. Paper Presented at the Regulation and Supervision of Microfinance Institutions (MFIs) in SAARC Region. Kathmandu, Nepal; Available online: http://www.nrb.org.np/saf/seminar/mfonsaarcregion/BangladeshCountry-Paper.pdf (accessed on 24 August 2018).

Akash, Mahbubul Mokaddem, Momtazuddin Ahmed, and Sayema Haque Bidisha. 2010. The NGO-MFI in Bangladesh: The Issue of Ownership and Governance. Paper Presented at the Microfinance Regulations: Who Benefits? Bangladesh Conference. Available online: http://www.microfinancegateway.org/library/ngomfi-bangladesh-issue-ownership-and-governance (accessed on 11 June 2019).

Alamgir, Dewan A. H. 2009. Microfinance in SAARC Country Overview Report. Dhaka: Institute of Microfinance (InM).

Armendáriz, Beatriz, and Jonathan Morduch. 2010. The Economics of Microfinance, 2nd ed. Cambridge: MIT Press. Bakker, Anuschka, Jaap Schaveling, and Andre Nijhof. 2014. Governance and microfinance institutions. Corporate Governance 14: 637-52. [CrossRef] 
Banerjee, Subhabrata Bobby, and Laurel Jackson. 2017. Microfinance and the business of poverty reduction: Critical perspectives from rural Bangladesh. Human Relations 70: 63-91. [CrossRef]

Bansal, Hema, Tanwi Kumari, Aditya Mohan, and Amit Gupta. 2013. Implementing Client Protection in Indian Microfinance. Available online: http://smartcampaign.org/storage/documents/SOP_India_Booklet_Final_1612-2013_Hi-Res.pdf (accessed on 20 August 2018).

Bateman, Milford. 2012. How Lending to the Poor Began, Grew, and Almost Destroyed a Generation in India. Development and Change 43: 1385-402. [CrossRef]

Baten, Waliul. 2009. Vision of Microfinance in Bangladesh Success and Challenges. (Masters), Copenhagen Business School, Copenhagen Business School, Capital Region. Available online: http://studenttheses.cbs.dk/ bitstream/handle/10417/796/waliulbaten.pdf?sequenc (accessed on 9 April 2019).

Bedson, Jamie. 2009. Microfinance Industry Report Bangladesh 2009. Bangladesh: Credit and Development Forum.

Beisland, Leif Atle, and Roy Mersland. 2012. An Analysis of the Drivers of Microfinance Rating Assessments. Nonprofit and Voluntary Sector Quarterly 41: 213-31. [CrossRef]

Beltran, G. S. 2007. Microfinance Consumer Protection Guidebook. Mandaluyong: Asian Development Bank.

Berge, Lars I. O., Kartika S. Juniwaty, and Linda H. Sekei. 2016. Gender composition and group dynamics: Evidence from a laboratory experiment with microfinance clients. Journal of Economic Behavior E Organization 131: 1-20.

Bongomin, George Okello Candiya, Joseph Mpeera Ntayi, and John C. Munene. 2017. Institutional framing and financial inclusion. International Journal of Social Economics 44: 1727-44. [CrossRef]

Brix, Laura, and Katharine McKee. 2010. Consumer Protection Regulation in Low-Access Environments: Opportunities to Promote Responsible Finance. Washington: CGAP.

Charitonenko, S., and S. M. Rahman. 2002. Commercialization of Microfinance: Bangladesh. Mandaluyong: Asian Development Bank.

Chaudhury, Iftekhar A., and Imran Matin. 2002. Dimensions and dynamics of microfinance membership overlap-A micro study from Bangladesh. Small Enterprise Development 13: 46-55. [CrossRef]

Cheston, Susy, and Lisa Kuhn. 2002. Empowering Women through Microfinance. Available online: http://www. genfinance.info/documents/Gender20Impact/ChestonandKuhn_2002.pdf (accessed on 11 December 2019).

Chowdhury, Anis. 2000. Politics, Society and Financial Sector Reform in Bangladesh. Helsinki: UNU World Institute for Development Economics Research, vol. 191, p. 7.

Cohen, Monique. 2013. Broadening the financial literacy agenda. Enterprise Development and Microfinance 24: 179-82. [CrossRef]

Credit Development Forum (CDF). 2013. Bangladesh Microfinance Statistics. In CDF Report. Edited by A. Awal. Dhaka: Credit Development Forum (CDF).

D’Espallier, Bert, Isabelle Guérin, and Roy Mersland. 2011. Women and Repayment in Microfinance: A Global Analysis. World Development 39: 758-72. [CrossRef]

D’Espallier, Bert, Marek Hudon, and Ariane Szafarz. 2016. Aid Volatility and Social Performance in Microfinance. Nonprofit and Voluntary Sector Quarterly 46: 116-40. [CrossRef]

Dattasharma, Abhi, Rajalaxmi Kamath, and Smita Ramanathan. 2016. The Burden of Microfinance Debt: Lessons from the Ramanagaram Financial Diaries. Development and Change 47: 130-56. [CrossRef]

Deegan, Craig. 2014. Financial Accounting Theory. Sydney: McGraw Hill.

Drago, Carlo, and Andrea Gatto. 2018. A Robust Approach to Composite Indicators Exploiting Interval Data: The Interval-valued Global Gender Gap Index (IGGGI). In IPAZIA Workshop on Gender Issues. Cham: Springer, pp. 103-14.

Dzanku, Fred M. 2019. Food Security in Rural Sub-Saharan Africa: Exploring the Nexus between Gender, Geography and Off-farm Employment. World Development 113: 26-43. [CrossRef]

Epstein, Marc J., and Kristi Yuthas. 2017. Cash Flow Training and Improved Microfinance Outcomes. Journal of International Development 29: 106-16. [CrossRef]

Gatto, Andrea. 2018. Historical Roots of Microcredit and Usury: The Role of Monti di Pietà in Italy and in the Kingdom of Naples in XV-XX centuries. Journal of International Development 30: 911-14. [CrossRef]

Gertler, Paul J., Sebastian Martinez, Patrick Premand, Laura B. Rawlings, and Christel M. J. Vermeersch. 2011. Impact Evaluation in Practice. Washington, DC: World Bank. 
Ghosh, Partha, Richa Valechha, and Puneet Chopra. 2014. The Impact of Regulations on Microfinance Industry: A Strategic Perspective. Lucknow, India. Available online: http://www.microsave.net/files/pdf/Impact_of_ Policies_and_Regulations_on_the_Micro_finance_Sector.pdf (accessed on 24 July 2018).

Gutiérrez-Nieto, Begoña, Carlos Serrano-Cinca, and Marta de la Cuesta サGonzález. 2017. A Multivariate Study of Over-indebtedness' Causes and Consequences. International Journal of Consumer Studies 41: 188-98. [CrossRef]

Hair, Joel F., Jr., William C. Black, Barry J. Babin, and Rolph E. Anderson. 2014. Multivariate Data Analysis, 7th ed. Essex: Pearson International Edition.

Herman, Lauren. 2012. My Guide to Microfinance Lending. Berkeley: University of California.

Huston, Sandra J. 2010. Measuring financial literacy. Journal of Consumer Affairs 44: 296-316. [CrossRef]

Islam, Ezazul, and Salim Ali Mamun. 2011. Financial Inclusion: The Role of Bangladesh Bank. In Bangladesh Bank Working Paper. Translated by B. B. Research Department. Dhaka: Bangladesh Bank.

Islam, Khan Jahirul, and Wayne Simpson. 2018. Payday Lending and Microcredit: Two Faces of the Same Problem? Journal of International Development 30: 584-614. [CrossRef]

Jackson, Kenneth E., and Tazul Islam. 2005. Regulation of Microfinance NGOs: General Reflections and the Case of Bangladesh. International Journal of Rural Management 1: 45-57. [CrossRef]

Jha, Srirang. 2016. The Role of Microfinance in Social Development. Review of Knowledge Management 6: 15-19.

Kalra, Vinita, Himendu P. Mathur, and P. V. Rajeev. 2015. Microfinance clients' awareness index: A measure of awareness and skills of microfinance clients. IIMB Management Review 27: 252-66. [CrossRef]

Khalily, M. A. Baqui. 2016. Financial Inclusion, Financial Regulation, and Education in Bangladesh. ADBI Working Paper Series No. 621; Tokyo: Asian Development Bank Institute.

Khalily, M. A. Baqui, and Pablo Miah. 2015. Financial Literacy and Its Impact on Inclusive Finance in Bangladesh. Dhaka: Institute of Microfinance.

Kline, Kenny, and Santadarshan Sadhu. 2011. Consumer Protection Regulation. The Microfinance Review III: 15.

Lee, Jae M., Narang Park, and Wookjae Heo. 2019. Importance of Subjective Financial Knowledge and Perceived Credit Score in Payday Loan Use. International Journal of Financial Studies 7: 53. [CrossRef]

Maîtrot, Mathilde. 2018. Understanding Social Performance: A 'Practice Drift' at the Frontline of Microfinance Institutions in Bangladesh. Development and Change 50: 632-54. [CrossRef]

Miah, Mohammad Ayub. 2006. Regulatory Architecture for Microfinance in Asia. Tokyo: Asian Productivity Organization.

Microcredit Regulatory Authority (MRA). 2011. NGO-MFIS in Bangladesh. Dhaka: Microcredit Regulatory Authority (MRA).

Microcredit Regulatory Authority. 2010. MRA Rules. Available online: http://www.mra.gov.bd/images/mra_files/ Regulations/mra\%20regulations\%20\%20unofficial\%20translation\%20final.pdf (accessed on 2 February 2020).

Microfinance Regulatory Authority Act. 2006. Dhaka, Bangladesh. Available online: http://www.mra.gov.bd/ images/mra_files/mra_act_2006_english.pdf (accessed on 27 July 2019).

MIX Market. 2012. Available online: http://www.mixmarket.org/ (accessed on 11 June 2019).

Murendo, Conrad, and Kingstone Mutsonziwa. 2017. Financial Literacy and Savings Decisions by Adult Financial Consumers in Zimbabwe. International Journal of Consumer Studies 41: 95-103. [CrossRef]

Nawaz, Faraha. 2015. Microfinance, Financial Literacy, and Household Power Configuration in Rural Bangladesh: An Empirical Study on Some Credit Borrowers. Voluntas 26: 1100-21. [CrossRef]

Perdomo, Maria. 2008. Consumer Protection: A Client Perspective. Washington: Microfinance Opportunities.

Rahman, M. Wakilur, and Jianchao Luo. 2012. Regulation of Microfinance service provider in China and Bangladesh: An approach to strengthening regulatory environment. African Journal of Business Management 6: 1033.

Rashid, Lila. 2010. Microfinance Regulations in Bangladesh: Development \& Experiences. Paper Presented at the Microfinance Regulation: Who Benefits? Dhaka. Conference Paper. Available online: http: //www.scribd.com/doc/52177499/Bangladesh-MRA\#scribd (accessed on 11 March 2019).

Rozas, Daniel, Isabelle Barrès, Charlotte Connors, and Elisabeth Rhyne. 2011. Implementing Client Protection in Microfinance the State of the Practice. A Report from the Smart Campaign. Washington: Center for Financial Inclusion.

Rusciano, Vincenzo, Debora Scarpato, and Gennaro Civero. 2019. Territorial Social Responsibility: A Cluster Analysis on a Case Study. Calitatea 20: 543-48. 
Sayinzoga, Aussi, Erwin H. Bulte, and Robert Lensink. 2016. Financial Literacy and Financial Behaviour: Experimental Evidence from Rural Rwanda. Economic Journal 126: 1571-99. [CrossRef]

Schicks, Jessica. 2014. Over-Indebtedness in Microfinance-An Empirical Analysis of Related Factors on the Borrower Level. World Development 54: 301-24. [CrossRef]

Shahriar, Abu Z. M., Luisa A. Unda, and Quamrul Alam. 2020. Gender differences in the repayment of microcredit: The mediating role of trustworthiness. Journal of Banking E Finance 110: 105685.

Shinozaki, Shigehiro, Alexandra Rizzi, and Hema Bansal. 2017. Microfinance Client Protection in Asia and the Pacific: Lessons from ADB-Smart Campaign Training Programs. ADB Briefs, Paper No. 74. Mandaluyong: Asian Development Bank.

Solli, Jami, Arthur Goujon, and Michael Gaweseb. 2011. A Guide to Developing Consumer Protection Law. London: Consumers International.

Thaler, Richard. 1985. Mental accounting and consumer choice. Marketing Science 4: 199-214. [CrossRef]

The World Bank. 2018. GDP per Capita. Available online: https://data.worldbank.org/indicator/NY.GDP.PCAP. CD?locations=BD (accessed on 6 April 2019).

Tiwari, Akhand, Anvesha Khandelwal, and Minakshi Ramji. 2008. How Do Microfinance Clients Understand their Loans? Channai: Institute for Financial Management and Research.

Wickramasinghe, Vathsala, and Dilshan Fernando. 2017. Use of Microcredit for Household Income and Consumption Smoothing by Low Income Communities. International Journal of Consumer Studies 41: 647-58. [CrossRef]

World Economic Forum (WEF). 2020. Global Gender Gap Report 2020. Geneva: World Economic Forum.

Yuge, Yasuhiko. 2011. The Current Situation of Microfinance in Bangladesh: A Growing Concern about Overlapping Loan Problems-From a Field Visit to Rajshahi and Comilla. Medford: Center for Market Enterprises, Fletcher School, Tufts University.

Publisher's Note: MDPI stays neutral with regard to jurisdictional claims in published maps and institutional affiliations.

(C) 2020 by the authors. Licensee MDPI, Basel, Switzerland. This article is an open access article distributed under the terms and conditions of the Creative Commons Attribution (CC BY) license (http://creativecommons.org/licenses/by/4.0/). 